\title{
Habitat alteration and mortality of adult leatherback turtles in Gabon, Central Africa
}

\section{MaIte IKaRAN}

Universidad de Las Palmas de Gran Canaria.

maiteikaran@gmail.com

\section{ABSTRACT}

The Republic of Gabon (Central Africa) hosts the largest nesting aggregation in the world for the leatherback turtle Dermochelys coriacea (Vandelli, 1761) with the Guianas in South America. A research on its reproductive ecology was carried out during three consecutive seasons (2005/2008) at the beach of Kingere in Pongara National Park. This is a wild beach where no previous studies had been undertaken before and one of the main objectives was to determine the main threats to the species at the site. We found that there can be a considerable mortality of adult females caused by the many stranded logs (or lost timber) on the beach. The position of the logs constitutes sometimes a lethal trap for nesting leatherbacks that die from the shock or dehydration without being able to return to the sea. During the course of $2006 / 2007$, local NGO staff performed more than 30 rescue operations allowing trapped females to return alive to the sea. This is certainly one of the major environmental problems on the coast of Gabon not only in terms of habitat alteration but also for the conservation of Dermochelys coriacea.

KEY WORDS: Gabon, Leatherback, Pongara National Park, Kingere, nesting beach, stranded logs, Dermochelys coriacea, sea turtle conservation.

\section{RESUMEN}

La República de Gabón alberga uno de los puntos más importantes en todo el mundo para la anidación de la tortuga laúd, Dermochelys coriacea (Vandelli, 1761). Entre los años 2005 y 2008, se llevó a cabo un estudio sobre el estado de conservación de esta especie en una playa hasta ahora desconocida para la comunidad científica, dentro del Parque Nacional de Pongara. Uno de los hallazgos más destacados fue la alta mortalidad de hembras adultas debido a los troncos varados en la playa. Estos troncos, de enormes dimensiones, proceden de la industria maderera y constituyen una trampa mortal para las hembras anidantes. Durante la temporada 2006/2007, se llevaron a cabo cerca de 30 operaciones de rescate a cargo de los guardas locales del Parque Nacional, permitiendo devolver a las hembras con vida al mar. Este es un problema medioambiental grave, que afecta no sólo a las tortugas marinas, sino también al hábitat costero en general.

PALABRAS CLAVES: Gabon, laúd, Pongara National Park, Kingere, playa de anidación, troncos varados, Dermochelys coriacea, conservación de tortugas marinas.

\section{LABURPENA}

Gaboneko Errepublika mundo mailan Dermochelys coriacea (Vandelli, 1761), larruzko dortokaren errute hondartza gune garrantzitsuenetako bat da. 2005-2008 urte bitartean, espeziearen kontserbazio egoeraren inguruko ikerketa bat burutu zen, komunitate zientifikoak orain arte ezagutzen ez zuen Pongara Parke Nazionaleko hondartza batean. Aurkikuntza adierazgarrienetariko bat, errutera irteten ziren emeen heriotze tasa altua izan zen, hondartzaratuta zeuden enborretan kateatuak geratzen bait ziren. Enbor ikaragarri hauen jatorria, egur-industria da eta tranpa hilkorra bertan erruten duten emeentzat. 2006/2007 denboraldian, 30 erreskate ekimen burutu zituzten Parke Nazionaleko zaindariek. Hau ingurugiro arazo larria da eta itsas dortokei ez ezik kostaldeko habitatari ere erasaten dio oro har.

GAKO-HITZAK: Gabon, larruzko dortoka, Pongara National Park, Kingere, errute hondartza, hondartzaratutako enborrak, Dermochelys coriacea, itsas dortoken kontserbazioa.

\section{INTRODUCTION}

Along with the Guianas, the Republic of Gabon (Central Africa) hosts the largest nesting aggregation in the world for the leatherback turtle Dermochelys coriacea (Vandelli, 1761) (WITt et al., 2009), yet there is still a paucity of detailed knowledge of many key aspects about reproductive ecology at the site (FRETEY et al., 2007). Pongara National Park is one of the main protected areas along the coast. The beach of Kingere, with an estimated 170 to 450 nests per kilometer, remains almost virgin and can be considered as a hotspot for this species in Gabon (IKARAN, 2010). From 2005 to 2008, a study on the nesting ecology of $D$. coriacea was conducted at Kingere so as to determine and quantify the main natural and/or anthropogenic threats to the species at the different life-stages.

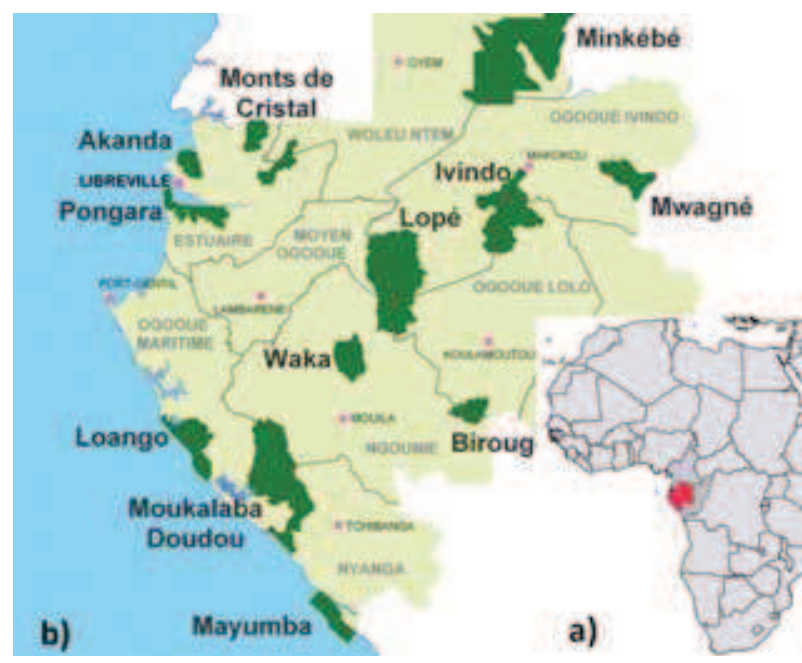

Fig. 1.- (a) Location of the country of Gabon in Central Africa (in red) and (b) the 13 National Parks in Gabon, including Pongara, the study site. 


\section{METHODS}

The research was carried out at the beach of Kingere in Pongara National Park ( $0^{\circ} 18^{\prime} \mathrm{N}, 9^{\circ} 18^{\prime} \mathrm{E}$; Fig. 1) during 3 consecutive seasons (2005/2008). The nesting season for the leatherback in Gabon spreads from November to march, with a peak of activity during December and January. Local NGO Gabon Environnement provided logistic support at a beach-based research camp. Basic monitoring activities included night patrols for female identification and in situ nest marking as well as early morning track counts. These were carried out by local guards of the NGO and the National Park that had been specifically trained in marine turtle manipulation techniques.

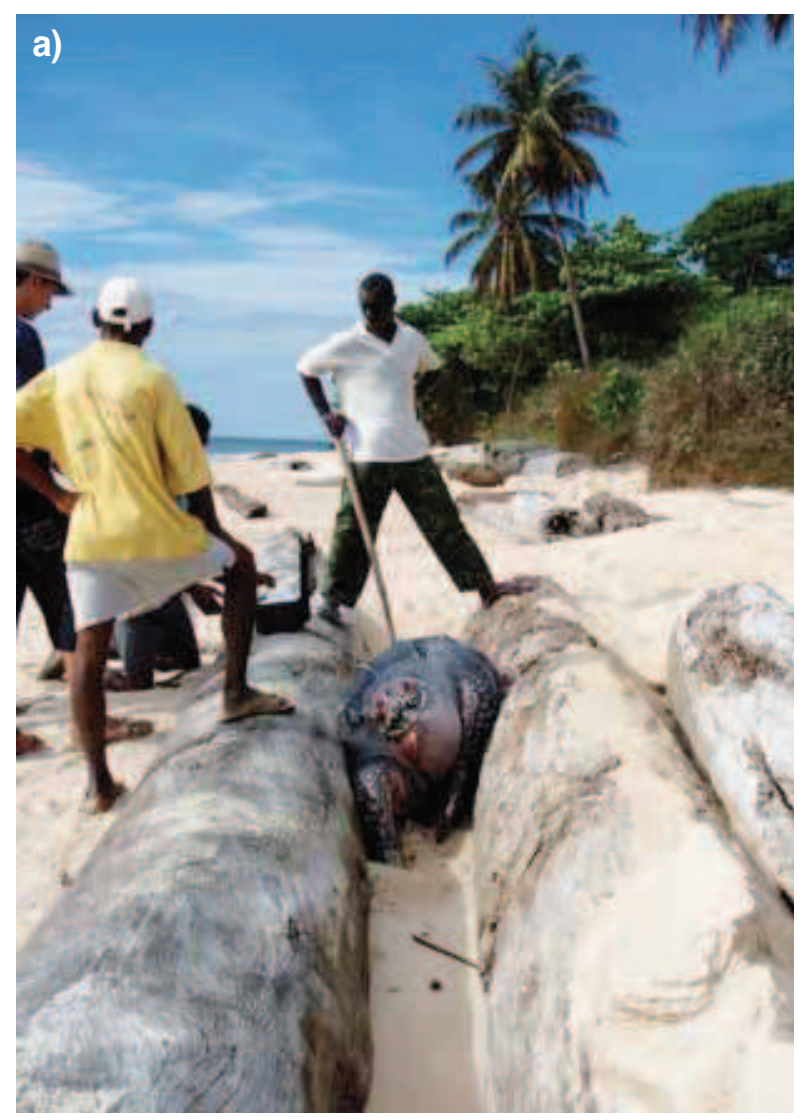

Fig. 2.- (a, b, c, d) Dead females among stranded logs.

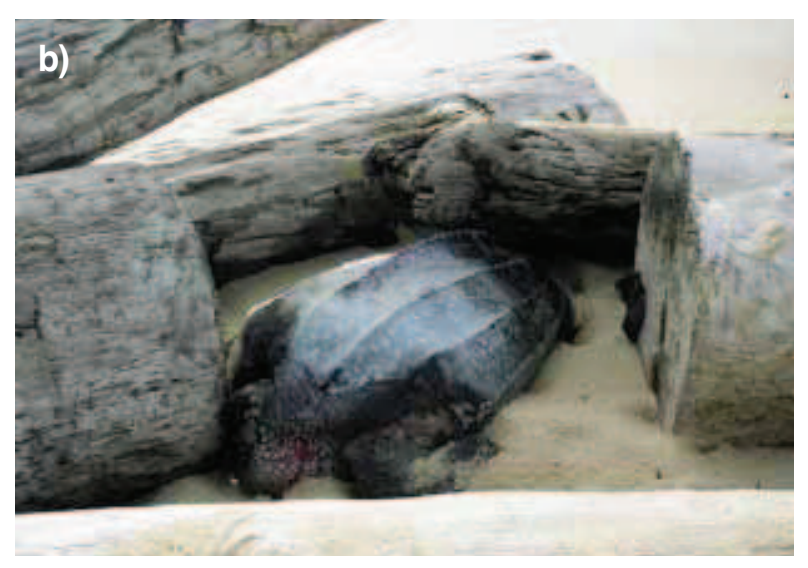

\section{RESULTS}

We identified an unusual source of adult female mortality at the beach of Kingere caused by the high incidence of stranded logs originated from timberland activities. The logs were positioned in such a way that they constituted lethal traps for the females, that get caught in between them and cannot go back to the sea. If rescue operations by the local guards were not performed in time, females would die from dehydration or the shock. During the month of November 2006, we counted 15 dead females at Kingere among the logs (Fig. 2). This happened because the guards were not on duty yet. Once the monitoring activities started, we performed 28 rescue operations during the rest
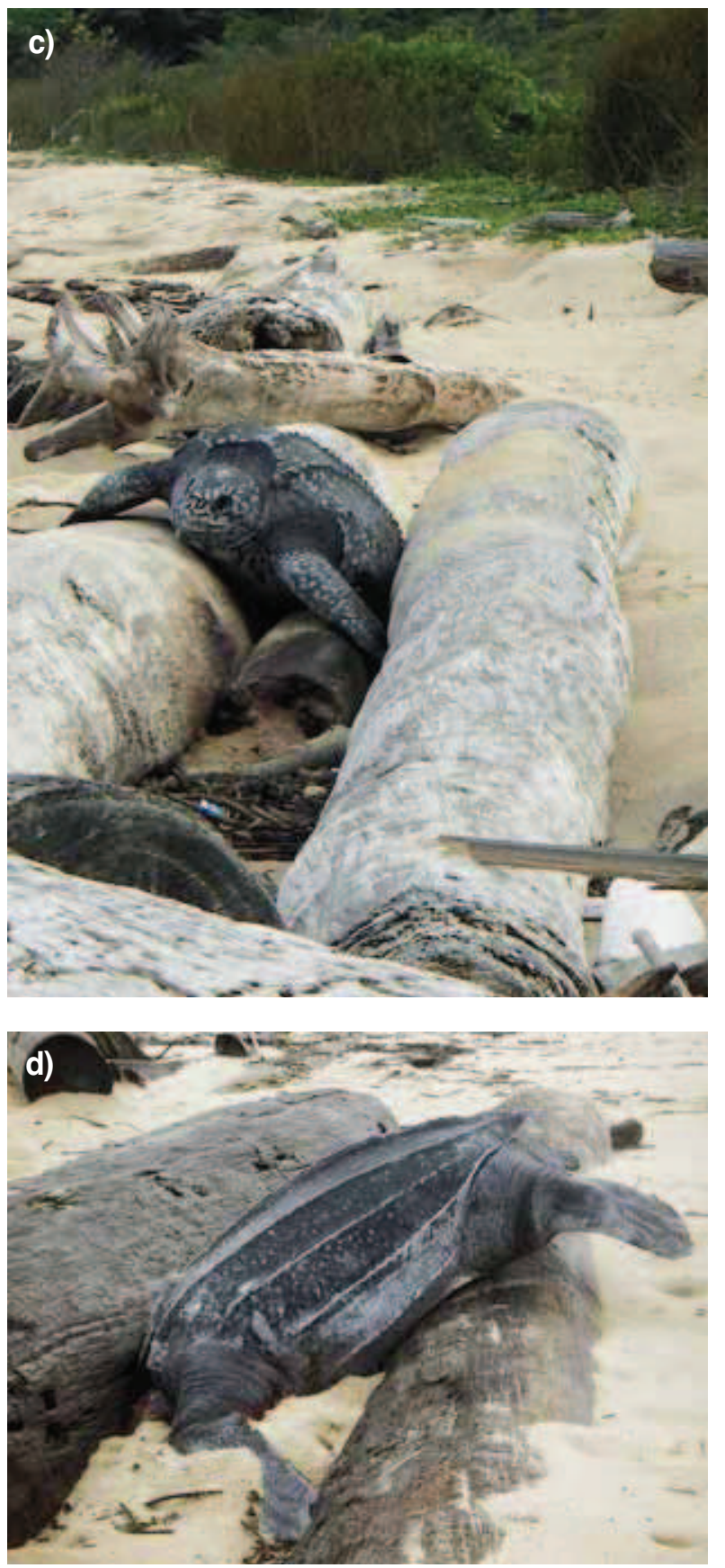
of season 2006/2007. These were sometimes complicated, due to the weight of the female and the position in which the female was usually found. The best technique to release the female, was by passing harnesses below the armpit; two people pulled the female this way, while a $3^{\text {rd }}$ or $4^{\text {th }}$ person would push forward from the back (Figure 3). The female should not be pulled by the caudal projection, as this is a very fragile part of the body. Sometimes females had to be pushed until they reached the sea, because they were already very debilitated and not able to crawl on the sand. However, the contact with seawater seemed to reanimate them as they instantly started to swim offshore. Some females, would also get injured by the logs (Figure 4), as these have oxidized metal rings attached. We were able to identify such scars in the head, flippers and carapace of several nesting females.

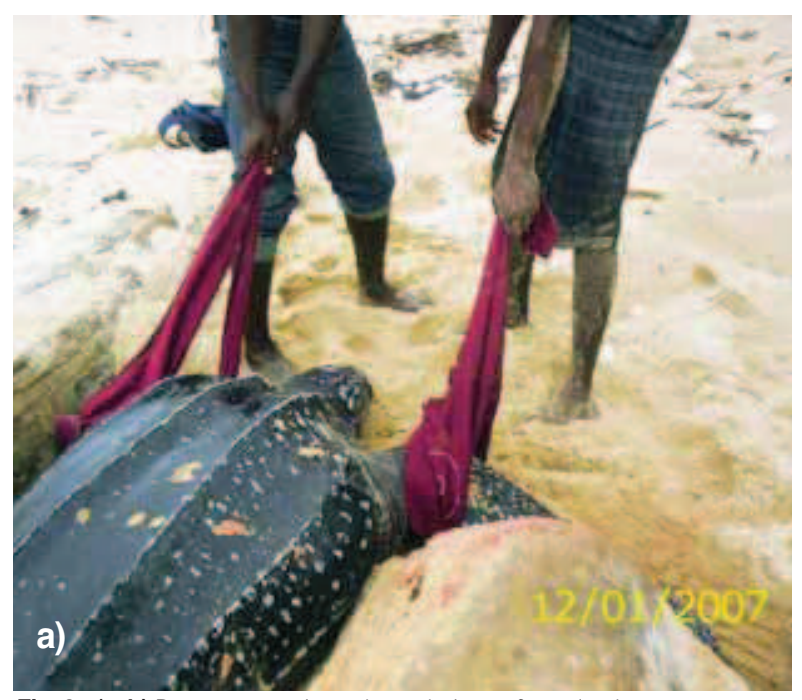

Fig. 3.- (a, b) Rescue operations: the technique of passing harnesses or pulling from below the armpits.

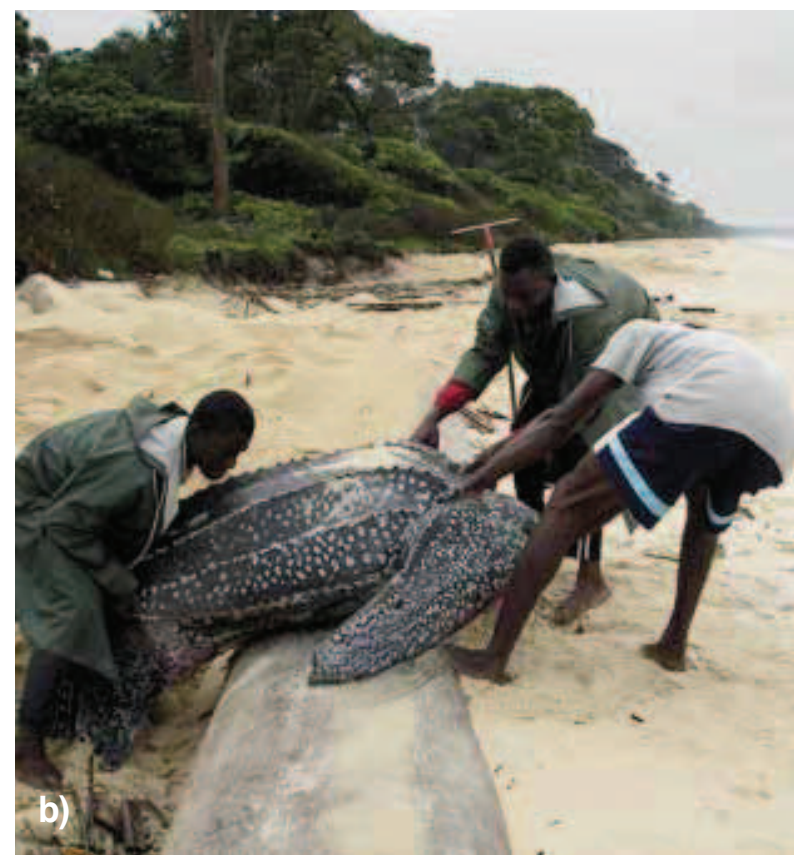

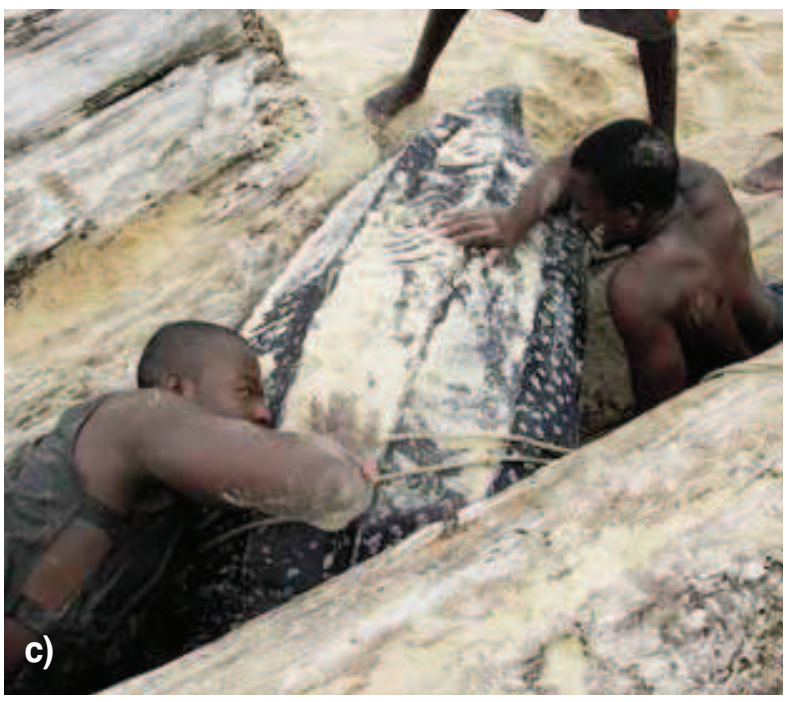
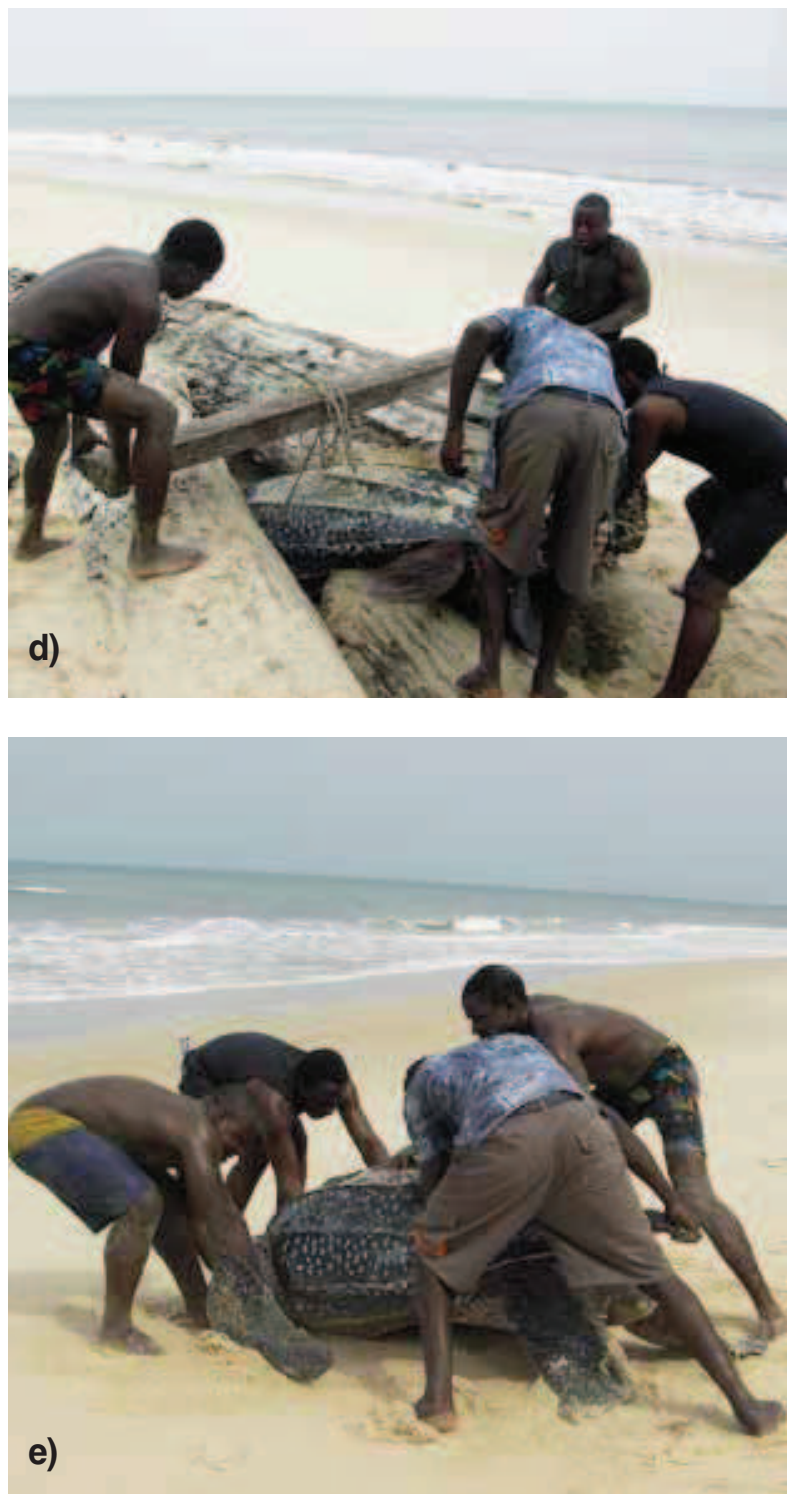

Fig. 3.- (c, d, e) Rescue operations: sequence of the release of a female that was trapped among the logs. 


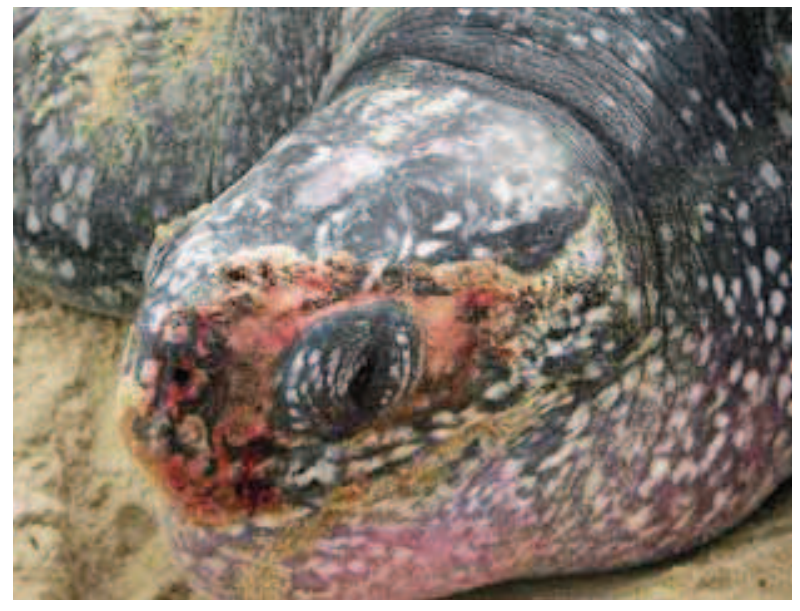

Fig. 4.- Female showing injuries in the head due to the oxidized metal rings.

\section{DISCUSSION}

The high incidence of logs at the beach of Kingere was found to be a major hazard to nesting females and is probably one of the major environmental threats to the coastal area in general. During this study, we also found that there is an equal or even higher amount of buried logs beneath the sand (IKARAN, 2010). Hence, the visible stranded logs might be only the tip of the iceberg of the problem. Buried logs slowly decompose and represent a source of organic material as well as an attraction point for invertebrates and microorganisms, that might be negatively affecting the incubation of nests (IKARAN, 2010).

The logs are originated from inland timberland activities (LAURENCE et al., 2008). Harvested logs are transported via rivers on barges or cabled together into floating rafts to open sea and then the major ports (see references in LAURENCE et al., 2008). During transport, some of these logs, that can measure up to $15 \mathrm{~m}$ in length and $120 \mathrm{~cm}$ diameter, might be accidentally or intentionally (because being defective) lost and end up on the stranded on the coast. LAURENCE et al. (2008) quantified the occurrence of logs all over the coast of Gabon and confirmed the magnitude of this problem not only as a threat to sea turtles but also as an economic waste. The incidence of logs seems to be particularly high at Pongara, blocking up to $30 \%$ of the beach at some critical points.

This problem has a difficult solution because of legal and logistic conditions. First, it is not possible, by law, to exploit in situ this wood because, the logs are already owned by the forestry companies. Second, the removal of logs would only be possible with heavy machinery and this would cause a negative impact on the coastal habitat. Considering that the presence of logs is generalised all along the coast of Gabon and probably the neighbouring countries (LAURENCE et al., 2008), the numbers of dead adult females every season may reach alarming numbers at a regional scale. A similar mortality has been described in the Guianas, where nesting females can get trapped in between the logs originated from the mangroves behind the beaches (FRETEY, 1977; FRETEY, 1981). In this case, however, this is due to natural coastal dynamics processes during which mangroves are eroded away by the sea (Jacques Fretey, pers. comm.).

As far as management and conservation are concerned, rescue operations alone justify by far the need of regular surveillance of the beach by local guards, because it implies saving adult females. These should be maintained and extended to neighbouring beaches until the problem of logs is solved.

\section{CONCLUSIONS}

The high incidence of stranded logs on the beach is the main threat to $D$. coriacea and has an anthropogenic origin.

By patrolling the beaches regularly, the staff from local NGOs, can save substantial numbers of females every season. Female rescue operations alone are well worth the cost of running a conservation project because it implies saving adult individuals that have a higher reproductive value than eggs.

The problem of logs should be considered from two perspectives; the first one involving the elimination of the existing logs on the beaches and the second one involving the eradication of the source of the problem.

\section{6.- ACKNOWLEDGEMENTS}

This work was possible thanks to a Research Grant from Departamento de Educación, Universidades e Investigación del Gobierno Vasco. I would like to acknowledge the local ecoguards, for their help during field work and the Gabonese authorities for letting me carry out this work. I would also like to thank Nagore Zaldua-Mendizabal for bringing to me the opportunity to participate in this edition of Munibe Monographs. Nature Series.

\section{REFERENCES}

FreteY, J. 1977. Causes de mortalité des Tortues luths adultes (Dermochelys coriacea) sur le littoral guyanais. Courr. Nat. 52: 257-266.

FreteY, J. 1981. Tortues marines de Guyane. Editions du Léopard d'or. Paris.

Fretey, J., Billes, A., Tiwari, M. 2007. Leatherback, Dermochelys coriacea, Nesting Along the Atlantic Coast of Africa. Chelonian Conserv. Biol. 6(1): 126-129.

IKARAN, M. 2010. Nesting and Conservation of the leatherback turtle, Dermochelys coriacea, at the beach of Kingere, Gabon, Central Africa. PhD thesis. Universidad de Las Palmas de Gran Canaria.

Laurance, W. F., Fay, J. M., Parnell, R. J., Sounget, G. P., Formia, A., LEE, M. 2008. Does rainforest logging threaten marine turtles?. Oryx 42(2): 246-251.

Witt, M. J., Baert, B., Broderick, A., Formia, A., Fretey, J., GoBuid, A., Mounguengl, G. A., Moussounda, C., Ngouessono, S., Parnell, R.J., Roumet, D. Sounguet, G. P. Verhage, B., Zogo, A., GodLEy, B. J. 2009. Aerial surveying of the world's largest leatherback turtle rookery: A more effective methodology for large-scale monitoring. Biol. Conserv.142(8): 1719-1727. 